\title{
Financial Literacy among Lebanese Youth
}

\section{Dr. Racha Ghayad}

Assistant Professor, Head of Finance Department, Faculty of Economic Sciences and Business Administration, Lebanese University, Lebanon

\section{Saria Hasan Shayya}

Master's degree in Finance and Banking, Lebanese University, Lebanon

\begin{abstract}
:
Financial literacy is a skill needed by every individual to manage personal money, take daily financial decisions and plan for future. It is the understanding of basic financial concepts and implementing them into person's life.
\end{abstract}

Youth are tomorrow's economy builders, for that they should understand the value of money so they can handle their finances better, know the importance of savings, budgeting, insurance, pension plans, etc...

Financial services became more available and easily accessed, which put a pressure on youth to properly use them otherwise they will sink in debts, for that this research highlights on the importance of educating youth financially, the study is an empirical study that mainly evaluate to what extent do Lebanese youth have knowledge about their personal finance.

Keywords: Financial Literacy, Lebanon, Youth, Education 


\section{الثقافة المالية بين الثباب اللبنانى}

المعر فة المالية مهارة يحتاجها كل فرد لإدارة أمو اله الثخصية واتخاذ قرار اته المالية اليومية والتخطبط للمستقبل. تساعد المعرفة المالية في فهم المفاهيم المالية الأساسية وكيفية تطبيقها. الثباب هم مستقبل الاقتصاد، لذلك يجب ان يتمتعوا بالدراية الكافية بمفهوم المال ليتمكنوا من التعامل مع أمو الهم بشكل أفضل، ومعرفة أهمية المدخر ات، الميزانية، التأمين، و التخطيط للتقاعد... أصبحت الخدمات المالية أكثر توفراً وسهولة، مما يشكل ضغطاً على الثباب لاستخدامها بشكل صحيح و إلا فإنهم سيغرقون في الديون، من هذا المنطلق فان هذا البحث يسلط الضوء على أهمية تعليم الثباب ماليا. الدراسة تقيّم بشكل رئيسي

$$
\text { المعرفة المالية لاى الثباب اللبناني. }
$$

الكلمات المفتاحية: المعرفة المالية، لبنان، الثباب، التعليم.

\section{Introduction:}

The purpose of this study is to assess the financial literacy among Lebanese youth. The youth as defined by UNICEF are individuals between 18 and 24 years old.

Low financial skills led to many financial crises worldwide, for that the financial literacy became a global concern. World bank has evaluated the knowledge in personal finance low everywhere, for that OECD was established that is meant by evaluating, organizing conferences, workshops, educational guides, ... that help in developing financial knowledge in high-income and low-income countries. Policymakers in Arab region recently became also concerned in financial literacy programs because of the low rate of financial knowledge in the region (33\%), Lebanese adults specifically are $44 \%$ financially literate(S\&P Fin Lit survey).

Youth are builders of future economy and the keepers of its present stability in developed countries. For that, and from the early beginning of the education they should be literate in dealing with money and personal finance. Lebanese curriculums lack financial skills education, and other than business students and especially in department of finance minor students have acquired the minor knowledge in financial basic terms. The study shows in percentages and relations to what extent are Lebanese youth literate about personal finance and address the weakness. 


\section{Background of the study:}

The term financial literacy was first highlighted on in 1787 in the USA, when John Adams admitted in a letter to Thomas Jefferson that financial illiteracy was a reason behind the distress in America due to ignorance towards credit, circulation and nature of coin (Financial Corps, 2014). Thereafter, several developments took place and the term financial literacy was used repeatedly by researchers.

Financial literacy is a life skill composed of financial knowledge and its applications that are developed through personal finance education. Financial literacy influences financial behaviors along with other influencers such as culture, economy, and personality characteristics (Britt et al., 2013; Huston, 2010). Lusardi and Mitchell (2014) define financial literacy as the ability to "process economic information and make informed decisions about financial planning, wealth accumulation, debt, and pensions. The OECD's International Network on Financial Education, as well as others including Amagir et al. (2017), delineate three key components of financial literacy: knowledge and understanding, behavior, and attitudes and confidence. In any case, a comprehensive definition should reflect the idea that; as stated in the 2017 Jumpstart National Standards; "financial literacy is more than just knowledge and information". Additionally, having a clear outcome as part of the definition is beneficial in directing education efforts. This outcome should center on some element of financial wellbeing, broadly defined as long-term financial security and the avoidance of suboptimal financial decision-making.

Financial knowledge and skills can translate into positive financial behaviors, and are strongly correlated with budgeting, paying and tracking bills, maintaining a diversified portfolio, and holding emergency fund and savings. Core financial literacy concepts include according to (Jumptart, 2017) broad topic domains such as: spending, budgeting, and saving; investing; credit and debt; taxes; insurance; banking; fraud and identity theft, employment and income

History has recorded many inappropriate financial decisions. Money has often been a cause of the delusion of multitudes. Many crises took place as a result of micro and macro decisions lacking financial knowledge and resources, 
for that financial literacy became an important material for education in the $20^{\text {th }}$ century on the level of personal finance by which individuals and households acquire, develop, and allocate financial resources to satisfy their current and future financial needs. Financial education is concerned with skills, understanding, and behaviors toward money matters (Schuchardt, Bagwell, Bailey, DeVaney, Grable, Leech, Lown, Sharpe \& Xiao, 2007). As Schuchardt et al., (2007) stated, in the realm of personal finance, decision makers are central; the more skillful an individual becomes in managing money, the more possible it is to meet the individual's dreams (National Endowment for Financial Education [NEFE], 2010). Personal finance education establishes a future financial stability of individuals, and protects the national finance on the long run as well.

\section{What is Financial education:}

Financial education is key to a better financial behavior, reduction of bad debts, protect clients, achieve financial stability and contribute financial markets progressive development . It develops rates of financial systems inclusion and to broader economic and social development goals. Financial education is therefore increasingly being a mandatory requirement for many countries. Many stakeholders, central banks, policymakers and financial supervisors in commercial banks and insurance companies are interested in developing consumer awareness and financial literacy Considering the need for coordination among these players, a number of countries have developed or are in the process of developing national financial education strategies.

Financial education empowers citizens to make the best choices for their financial wellbeing. Financial literacy as seen by many researchers is inessential life skill for consumer protection. Moreover, increased savings and demand for financial services in the economic and financial sector growth should be contributed with adequate financial education.

New financial challenges are faced by youth in recent decades due, that require financial education and competences by them. Younger generations will face increasing financial risks, and will be confronted with more sophisticated financial products than did previous generations. They are now given access to financial services and products at an ever-younger age. However, 
these developments do not appear to be matched by an equivalent increase in their financial skills.

\section{The importance of financial literacy for youth.}

Inadequate financial knowledge and skills are considered as contributing to unsustainable levels of household debt, an increase in bankruptcies, and a decline in savings (Fox et al, 2005). With the progressive growth in the number and complexity of financial products available for everyone, the need for financial education for children, teens, and youths has never been greater, as there is substantial evidence that financial literacy programs in general, as well as programs aimed at children and youths, are successful in helping to improve levels of financial capability. With all this increased consumer pressure, countries are having a high concern in financial guidance and education to establish a skilled financial behavior and increase awareness among youths. And that by devoting significant resources to financial education in schools and community.

Illiterate financial decisions in communities would lead to crises as the world money crises of 2008, A personal mismanagement of money and illiterate financial decisions lead to person's bankruptcy and affect negatively country's macroeconomy.

Youth are tomorrow's economy builders and are the base of a sustainable economic growth and stability, for that educating them financially to know how to balance between their assets and debt, how to plan for their retirement, to know their social responsibility in paying taxes, how to insure for life, and the importance of savings and emergency funds all together prepares a skilled future citizens that would not sink in debts nor mismanage there money and country's resources with all the increased availability of financial products and credit cards

\section{Research Problem:}

The personal finance plays a significant role in modern society. A review of the literature, however, revealed some researches flaws. No study tends to investigate the financial knowledge level of the Lebanese youth in isolation. For that this empirical study aims to establish to what extent do the Lebanese youth have financial knowledge (dependent variable) in making personal finance decisions. In other words, 
The main thesis understudy in our research is:

Are Lebanese youth literate about financing personal money?

Additional research questions were designed to measure participants' financial knowledge in income and budgeting, money management, banking, investment, insurance, and saving, and to study the relationships between participants groups in terms of test scores or mean of differences.

\section{Methodology:}

We carried out the research with the articles referred to titles: financial literacy among youth, assessing financial literacy, financial education in Lebanon, and how to develop financial literacy. A quantitative research was conducted using a questionnaire uploaded on "Google Forms" filled by 492 youth, to test the hypotheses related mainly to personal finance and money management. Participants ages are between age 15 and 24 taking into consideration UNESCO's definition of youth. A bundle of tests was applied on the sample under study including Descriptive tests, inferential tests; chi square, independent $\mathrm{t}$ test and one-way Anova, and modulation tests; factor analysis studied how different financial behaviors are grouped in an associating mode.

This research attempted to find the significant low levels of financial literacy among the Lebanese youth. Hypotheses were drawn concerning the relationships between financial knowledge and different factors including age, gender, and financial education. In addition to the youth's involvement in family's financial decisions, work experience andfinancial inclusion.

\section{Hypotheses:}

- To what extent do Lebanese youth have knowledge about personal finance.

- To what extent do participants with financial background have better financial behavior than those without financial education background.

- If there is a relation between age and level of financial knowledge

- If there is difference in financial confidence between males and females

- If setting monthly household budget have an influence on youths' budgeting behavior.

- To What extent are Lebanese youth financially inclusive. 
- How can the Lebanese youth be classified based on their financial knowledge in comparison with other countries?

- Whether youth involved in family financial decision-making are more risk takers in investing their savings?

- If Lebanese youth show interest in attending personal finance courses.

By the analyzing the participants responses a final evaluation will answer the thesis question; Are Lebanese youth literate about personal money management?

\section{Keywords and Definitions:}

Financial literacy: "Financial literacy refers to the set of skills and knowledge that allows an individual to make informed and effective decisions through their understanding of finances." (Norman, 2010). The Government Accountability Office (GAO) also defines financial literacy as "the ability to make informed judgments and take effective actions regarding the current and future use and management of money" (Harnisch, 2010)

Youths: According to UNESCO, "Youth is best understood as a period of transition from the dependence of childhood to adulthood's independence and awareness of our interdependence as members of a community" and age has been considered as the easiest way to define youth by UNESCO which has indicated youth as a person between the age of leaving compulsorily education and finding first employment. UN has defined youth as the persons ranging between the age group of 15-24 years, for ensuring statistical consistency in international programs

Financially Educated Person: "Is a person who is financially literate and is able to allocate finances objectively or wisely" (Norman, 2010).

SPSS: Statistical Package for the Social Sciences (SPSS) software. The SPSS is a powerful software tool for entering and analyzing data (Frankfort-Nachmias and Nachmias 2008). 


\section{Literature Review:}

Financial literacy is the ability to recognize and apply various financial skills, including personal financial management, budgeting, and investing. While traditional education seeks to develop the intellect, provide social needs, prepare individuals for careers, create a workforce, promote social or political systems, and boost the economy as a whole. According to Norman (2010), a financially literate person is the one who can allocate finances objectively or wisely.

Only one out of every three adults in the world understands basic financial principles, according to a World Bank survey. High debt, mortgage defaults, and insolvency can all result from a lack of skills. As Europe's population ages and public pensions shrink, governments are urging citizens to have a larger role in retirement planning.

Financial literacy in the Arab region has been low compared to other regions as evaluated by World Bank. Policymakers have begun to prioritize financial inclusion. Financial consumer protection and financial education have become a major topic among regulators and financial services providers. Little information about the effectiveness or impact of such initiatives in promoting better financial behavior, better protecting clients, or expanding use of formal financial services has been shared across the area.

A study was done in 2017 by researcher Ahmad Falah Alomosh in Emirate. The study deduced that Emirate's youth financial behavior is average in general, and they have the habit of discussing financial issues with their parents. Emirates' youth are financially inclusive where majority of youth have saving accounts and track their balances. In addition, more than half of them use prepaid cards. 33\% of Emirate's youth consider their budgets before purchasing and the greater percent of them save for emergencies. The study recommended to increase the role of media in spreading financial knowledge, financial institutes should play a role in increasing knowledge in financial basics as inflation and consequences of weak financial behavior. Literate Emirate's families as being a source of information for youth, Increase the awareness toward the managing consumption.

In Lebanon and over the last several decades, financial education initiatives have been of paramount concern to scholars, educators, community groups, businesses, government agencies, 
National and international organizations, and policy-makers to provide consumers with this public good (OECD, 2006; FLEC, 2011; Hogarth, 2006; NEFE, JumpStart Coalition for Personal Financial Literacy, 2008).

Finance Minister Raya Hassan described financial and economic literacy as an absolute necessity, not a luxury, at the 2010 OECD-Banque du Liban International Conference on Financial Education, because any society whose members lack awareness and knowledge about financial and economic issues, concepts, products, and policies is fertile ground for financial, economic, and political risks, where arbitrary and irrational financial choices increase with longterm knock-on effects. And that Lebanese youth must acquire economic and financial knowledge at a young age in order to understand advanced financial and economic products and services, as well as to assimilate the fundamentals of public finance, accounting and national accounts, growth, money, foreign trade, and stock exchange, debt dynamics, investment and so on.

Low levels of financial literacy have been observed, especially in isolated rural areas, according to the Lebanese central bank "BDL" in 2018. Initiatives to improve financial literacy must be large and scalable. Schools, workplaces, and community platforms should all offer unique opportunities to deliver financial education to a wide range of people. Furthermore, financial literacy initiatives should target vulnerabilities across regions and specific demographics, such as women and youth (BDL, financial inclusion demand side survey report, 2018). BDL recommended to evaluate Lebanese citizens financial inclusion level every two years.

"Injaz Lebanon organization" has been concerned with youths' wellbeing in different life skills through various projects. Since 2017 Injaz had programs teaching youth about financial literacy and personal economy. Some Lebanese banks such as "Bank Audi" and "Bank Byblos" published a series of multimedia explaining financial terms and skills to increase the financial inclusion, in addition; "Basel Flaehan finance institute" in partnership with "Ministry of Finance" published a series of guides under the titles "Lebanese people and money" and "Your right and your duties". 
Conscious efforts and initiatives have been made to provide financial education for allyouth, adults, families, and communities. Financial illiteracy is still a widespread and huge issue in Lebanon today. Financial illiteracy is excessively pronounced for the low-educated and lowincome populations. Recently we recognize increased efforts to promote the financial wellbeing of Lebanese citizens. A financial resource guides were developed as sources of inspiration for all Lebanese leadership to design self-suited financial capabilities. The initiatives - although increased- are not a national program, not sustainable. Youth financial literacy in Lebanon; as a basic skill educated; is still in the recommendations stage that cannot be considered as an actual national project.

\section{Interpreting the findings:}

This research attempted to find the significant low levels of financial literacy among the Lebanese youth. Hypotheses were drawn concerning the relationships between financial knowledge and different factors including age, gender, and financial education. In addition to the youth's involvement in family's financial decisions, work experience andfinancial inclusion. A survey was uploaded and filled by 492 anonymous participants representing Lebanese youth from different Lebanese high schools and university and from different regions. The responses were collected analyzed by means of SPSS and results for the research questions were deduced, in this section I will review each question with the corresponding findings and interpretation.

\section{To what extent do Lebanese youth have knowledge about personal finance?}

Participants in the study were asked different types of question, questions stating their personal finance behavior in real life, questions evaluating their financial background, and questions assessing their knowledge in specified financial basics. Out of the 492 participant, only $36 \%$ of them had attended a financial course, but when they were asked about financial basics learnt the rates were very low and did not exceed $21.7 \%$ who learnt about inflation and a very little percentage of them have learnt pension funds that are a basic element in personal financial planning. Other than financial classes, 
internet and media are being the source of knowledge for Lebanese youth (48.6\% seek financial information from internet and media) then comes the parents with 33.7\%. In the absence of Lebanese trusted governmental or organizational websites that offer accurate financial information and in the increased volume of personal blogs over media, erroneous information may lead to a bad decision-making and management in personal financing The majority of participants, $79.1 \%$, don't rely on budgeting to control their earnings and expenditures although it's a basic behavior in personal finance and that can be explained by the low knowledge in budgeting as $66.3 \%$ of participants don't know about budgeting. Saving behavior is also an application of a good financial planning but unfortunately only $24.4 \%$ of the participants always save and $40.7 \%$ sometimes do, but $41.7 \%$ of them needs to use these savings to satisfy their desires and needs. And only $22.8 \%$ of them sets long term financial terms and stick to them. Participants are also low literate in insurance only $14.6 \%$ have learnt about it and $63.4 \%$ have heard about and in application only $38 \%$ of participants' families have insurance policies other than car insurance. Therefore, Lebanese financial knowledge is low and that was also the deduced from the financial assessment, where participants answered 5 questions related to interest, inflation, money value, banking cards and insurance and $42.08 \%$ was the financial literacy rate among the sample

\section{To what extent do participants with financial background have better financial behavior than those without financial education background?}

Independent $\mathrm{T}$ test was applied to distinguish the significant difference in financial behavior in between the two groups, financially educated and financially uneducated, the financially educated group more often use mobile phone applications to pay and settle balances, less likely to pay penalties for not settling bills and debts on time, and are more often risk takers in investing savings. On the other hand, I failed to reject the hypotheses of no significant difference in behavior between participants' groups in the financial behaviors mean occurrence of borrowing to cover bills, the two groups rarely do so, especially with the high dependency on parents (79.5\% of participants don't have personal income) as a source of personal income, both groups rarely refer to a consultant when taking a financial decision same as individuals everywhere as world bank states, in the study financial literacy around the world, 
that referring to financial advisors in decision making is very low everywhere. Also both groups often discuss financial issues with parents and consider their budget before buying desired products and services, Lebanese financial crisis increased the rate of discuss financial issues in most gatherings but are these discussions based on scientific knowledge, and will it reflect in financial literacy in next generations is a big question that coming years will answer it.

\section{Is there a relation between age and level of financial knowledge?}

Chi square test was used in this test and a significant difference was deduced only $48.59 \%$ of the participants who have attended a financial course were between the age of 15 and 18 years old. 287 out of 492 of participants belong to this group and thus, $31 \%$ of the age group attended a financial course whereas $44.39 \%$ of the $2^{\text {nd }}$ group ( 19 to 24 years old) have attended a financial course thus we conclude that university students have a higher financial education than younger group (high school students), although both groups are considered below average in financial education.

\section{Is there difference in financial confidence between males and females.?}

In Arab region other than Emirates, men have higher financial literacy than woman ( $\& \& P$ fin Lit survey), I tested this relation among the participants. And results were that also among Lebanese youth males have a higher financial confidence and a better knowledge in personal finance basics and financial inclusion as well. This can be explained by the higher intervention of males in family's financial decisions $(28.86 \%$ of females are involved in decision making whereas $40.3 \%$ of males do), and that males are more financially inclusive than females $(14.43 \%$ of females have a saving account versus $23.88 \%$ of males do; $21.65 \%$ of females access financial accounts and services via phone versus $32.84 \%$ of males do; $8.6 \%$ of females use a debit card versus $19.9 \%$ of males do; and $12.37 \%$ of females use credit cards versus $18.41 \%$ of males). In addition, $29.55 \%$ of females have received financial education whereas $45.27 \%$ of males did. All these factors play a role in males having a higher financial literacy rate than females among the Lebanese youth. 


\section{Does setting monthly household budget have an influence on youths' budgeting behavior?}

Setting a monthly house hold budget organizes spending and allows for savings to achieve short and long-term financial goals. The best investment of parents is their children and passing good behaviors to them. $33.7 \%$ seek financial information from parents thus, a family with a good personal financing behavior will inherit this knowledge to the next generation. This conclusion was proved in the results from the One-way Anova that showed a significant effect of parents budgeting routine on youth's budgeting behavior.

\section{To What extent are Lebanese youth financially inclusive?}

Lebanese youth are financially exclusive as results show that only $18.3 \%, 13.2 \%, 14.8 \%$ and 26.2\% have a saving account, have a debit card, have a credit card and use mobile financial applications respectively. Low rate of income resources independency and high rate of families' low income $(73.17 \%$ of participants' families income $<1000 \$)$. And the low saving behavior of families where $51.8 \%$ of families can cover their living for 1 month only including $23 \%$ of them who can cover only 1 week without income. These factors play a role in being financially exclusive add to that the Lebanese financial and banking crisis that led to the distrust in the Lebanese banking sector in the last 2 years.

\section{Whether youth involved in family financial decision-making are more risk takers in investing their savings?}

Confidence is developed by experience, and in absence of an applicable financial education for youth, they gain their experience at home, through taking part in decision making. Investment is a core skill in personal finance and in increasing wealth. Risk should be taken in investment for that experience and confidence play a role in taking investment decisions. Independent t test was applied to test the significance of this relation and results showed that youth who are involved in family financial decision making are more risk takers in investing their savings than other youth.

\section{How can the Lebanese youth be classified based on their financial knowledge in comparison with other countries?}


Lebanese youth, have much lower financial knowledge in interest and inflation compared them to American youth, and that's because in US policy makers have a high concern in developing financial literacy especially after 2008 financial crisis that scientists consider lacking financial knowledge was one of its major roots. The programs put for educating children, youth, and adults about personal finance in application not only theories and by introducing financial literacy in schools all spread the knowledge in a wider manner. In Arab region, an evaluation for adult's financial literacy was published upon S\&P fin lit surveying; in comparison to the observed financial literacy rate of youth in this study; Lebanese youth $(42.08 \%)$ have a lower rate than Lebanese adults and Kuwait's (44\%).

\section{Do Lebanese youth show interest in attending personal finance courses?}

In the questionnaire, the participants were asked if they are interested in attending a course that teaches personal finance and money management, the majority of the participants showed interest with $50.3 \%$ answered by yes and $36.5 \%$ that they might attend it. While $13.2 \%$ of them were not interested. Personal finance education won't attract youth or even adults if not highlighted on it, and on its benefits on the present and future of generations. Youth lack information in financial terms, basics and role. To literate them financially a sustainable educational program is needed.

\section{Limitations of the study:}

This study was limited to the use of research assessment record for Lebanese youth's financial literacy without having the ability to compare its observations with previous records to reach a conclusion of whether the status of financial literacy among Lebanese youth is developing or not and that's due to the lack of records and quantitative studies in this domain.

Another limitation was that some organizations which worked on the financial literacy workshops didn't give permission to access the records - if found - considering the rate of financial literacy among the Lebanese youth they worked with. 
Covid pandemic, Lebanese financial crisis and continuous strikes in schools and public directorates, in addition to the electricity problem in Lebanon limited the study from applying a workshop to test what impact a financial course will have on the financial literacy level of high school students.

\section{Recommendations:}

This study was designed to understand to what extent do Lebanese youth lack basic knowledge in personal finance. Data was collected, analyzed and interpreted the results; however, the limitations of this study gives a greater opportunity for further applied examination of this issue for that I do recommend:

- $\quad$ Mandatory courses that cover personal finance and money management basic skills in schools and colleges for ages 15 years and above to promote financial education.

- Workshops and seminars for all youth, in all Lebanese regions not only for the poorest and that includes household budgets, retirement plans and insurance policy concepts, saving and investments, good and bad debts, financial inclusion, ...

- Television episodes and entertaining programs that familiarizes financial concepts to the public in a light not boring way.

- $\quad$ More studies to be done on different Lebanese demographics to have a better assessment of citizens' financial knowledge and fulfill the gaps.

- Finding trusted media sources for financial information in Lebanon through educational "edu", organizational "org" and governmental "gov" websites to spread an accurate information among youth who consider media and internet the primary source of information.

- $\quad$ Parents are youth's $2^{\text {nd }}$ source of financial information, for that and for a better financially literate future generation; parents should receive financial awareness courses through workshops and seminars.

\section{Conclusion:}

The level of financial literacy among Lebanese youth is not high. Youth generally demonstrated low levels of financial knowledge and application throughout the study. 
The study has confirmed that financial illiteracy is not only wide spread among Arab citizens and Lebanese adults but also among Lebanese youth. Many factors play a role in youth's illiteracy, lack of financial education comes first, then the lack of trusted sources of information and the illiteracy of parents, as well as families' low income, financial dependency of youth, low involvement in financial decision making and low financial inclusion.

Policymakers and educators in Lebanon should be concerned with applying financial awareness for citizens like other countries, and introduce a mandatory course in all high schools and colleges about personal finance in a theoretical and applied manner to literate generations financially. Parents need to demonstrate a positive financial behavior to pass it to their children, since previous studies records and throughout this study, parents did not show a good model in their financial behavior whether in setting budgets, saving, insurance, sharing with children financial decisions nor referring to financial consultants. Daughters should be more involved in family financial planning and decision making to experience a financial knowledge.

Many financial crises can be avoided by a better financial behavior on micro level. Youth same as another Lebanese citizens need to be empowered with financial knowledge for a better future for them and for the country.

\section{References:}

\section{Articles}

- Communication

- A note on financial literacy and socio-demographic factors

- Communication

- A note on financial literacy and socio-demographic factors

- Communication

- A note on financial literacy and socio-demographic factors

- Ahmad Falah ALomosh. financial literacy among Emirati youth, 2018

- Amagir, A, Groot, W, Maassen van den Brink, H, et al. (2017). Financial Literacy of High School Students in the Netherlands: Knowledge, Attitudes, Self-Efficacy, and Behavior (TIER WP 17/18). 
- Annamaria Lusardi and Olivia S. Mitchell, The Economic Importance of Financial Literacy: Theory and Evidence (2014)

- A.S. Norman, Importance of financial education in making informed decision on spending, 2010

- B. KRISHNAKUMARE, SAURABH SINGH and S. NIRANJAN, A Note on Financial Literacy and Socio-demographic Factors, Vol 17(3), September- December 2019.

- BDL, BDL Financial Inclusion Demad Side Survey Report: Implementation and Key Finding, 2018

- Bhushan, P. \&Medury, Y. 2013. Financial Literacy and its Determinants. International Journal of Engineering, Business, and Enterprise Applications, 4(2): 155- 160.

- Britt, S. L., Cumbie, J. A., \& Bell, M. M. (2013). The influence of locus of control on student financial behavior. College Student Journal, 47(1), 178-184.

- Brown, James, How Strong is the Link between Internal Finance \& Small Firm Growth? Evidence from Survey of Small Business Finances,2009

- Consumer Financial Protection Bureau, Building Blocks to Help Youth Achieve Financial Capability: A new model and recommendations, 2016

- Danna L Moore, Survey of Financial Literacy in Washington State: Knowledge, behavior, Attitudes, and Experiences, 2003.

- Eugster, M. Financial literacy and participation in risky asset markets: A spurious relationship. The University of Auckland Business School, 2013.

- Jane Schuchardt, Dorothy C. Bagwell, William C. Bailey, Sharon A. DeVaney, John E. Grable, et al. Personal Finance: An Interdisciplinary Profession, 2007.

- Lusardi, Annamaria, and Olivia S. Mitchell. 2007. "Baby Boomers Retirement Security: The Role of Planning, Financial Literacy and Housing Wealth.” Journal of Monetary Economics 54: $205-224$.

- Organization for Economic Cooperation and Development (OECD) (2014) PISA 2012 Results: Students and Money: Financial Literacy Skills for the 21st Century, vol. VI. Paris: OECD.

- World Bank, Financial education in the Arab World: Strategies, Implementation and Impact, 2016 
- 2017 JumpStart National Educator Conference.

\section{Books:}

- Chava Frankfort-Nachmias; David Nachmias, Research methods in the social sciences, 2008

- National Endowment for Financial Education [NEFE], Your Spending, Your Savings, Your Future, Beginner's Guide to Financial Readiness, 2010 edition.

- ORNELLA RICCI and MASSIMO CARATELLI, Financial literacy, trust and retirement planning

- Samantha Gorelick, Howto develop financial literacy.

\section{Websites:}

- Jumpstart Coalition |Advancing Financial Literacy for Students (jumpstart.org)

- www.institutdesfinances.gov.lb

- FINANCIAL LITERACY - Bank Audi

- www.injaz-lebanon.org

- Balancing Everything | Your One-Stop Shop For Anything Finance

- Home - Financial Literacy - Research Guides at Milwaukee Area Technical College $\underline{\text { (matc.edu) }}$

- P.R.O.B.E. - Potential Reentry Opportunities in Business and Education - Serving Cumberland, Dauphin, Lebanon \& Perry Counties (probepa.org)

- $\quad$ The Center for Educational Research and Development |CRDP Lebanon

- $\quad \underline{S} \& P$ Global FinLit Survey Global Financial Literacy Excellence Center (GFLEC)

- PowerPoint Presentation (gflec.org)

- Corporate Social Responsibility $\mid$ Major Programs | Financial Literacy | Lebanon | Byblos $\underline{\text { Bank }}$

- OECD Annual Report 2006 | OECD Annual Report | OECD iLibrary (oecd-ilibrary.org)

Doi: $\underline{\text { doi.org/10.52133/ijrsp.v3.28.10 }}$ 